\title{
"Politics and the political in critical discourse studies: state of the art and a call for an intensified focus on the metapolitical dimension of discursive practice"
}

\author{
Zienkowski, Jan
}

ABSTRACT

\begin{abstract}
Based on an overview of the ways in which politics and the political have been thought in critical discourse analysis (CDA), the author calls for a focus on the metapolitical dimension of discourse. The author develops his notion of metapolitics on the basis of post-foundational insights into politics, the political and processes of (de-) politicization. Metapolitics refers to projects and struggles where conflicting modes and models of politics clash. Metapolitical debates potentially reshape the structure of the public realm as well as the entities, borders and processes that constitute it. The author differentiates his descriptive and analytic use of the term from the way this signifier has been used programmatically by the antidemocratic New Right and its heirs. He demonstrates that metapolitical projects can be democratic as well as anti-democratic. In order to facilitate discourse analyses of metapolitical projects, debates and struggles, the author suggests that the metapolitical dimension of contemporary debates can be explored further by integrating insights from governmentality studies, studies of political rationality and the discourse theoretical logics approach with CDA. Moreover, a further exploration of the linguistic and textual underpinnings of metapolitics constitutes a promising pathway for future investigation. The study of metapolitics should be part and parcel of the transdisciplinary domain of critical discourse studies so that our understanding of the linguistic and non-linguistic features of metapolitical projects can be developed in equal measur...
\end{abstract}

CITE THIS VERSION

Zienkowski, Jan. Politics and the political in critical discourse studies: state of the art and a call for an intensified focus on the metapolitical dimension of discursive practice. In: Critical Discourse Studies, Vol. 16, no. 2, p. 131-148 (2019) http://hdl.handle.net/2078.3/204103 -- DOI : 10.1080/17405904.2018.1535988

Le dépôt institutionnel DIAL est destiné au dépôt et à la diffusion de documents scientifiques émanant des membres de l'UCLouvain. Toute utilisation de ce document à des fins lucratives ou commerciales est strictement interdite. L'utilisateur s'engage à respecter les droits d'auteur liés à ce document, principalement le droit à l'intégrité de l'œuvre et le droit à la paternité. La politique complète de copyright est disponible sur la page Copyright policy
DIAL is an institutional repository for the deposit and dissemination of scientific documents from UCLouvain members. Usage of this document for profit or commercial purposes is stricly prohibited. User agrees to respect copyright about this document, mainly text integrity and source mention. Full content of copyright policy is available at Copyright policy 


\section{Critical Discourse Studies}

\section{Politics and the political in critical discourse studies: state of the art and a call for an intensified focus on the metapolitical dimension of discursive practice}

\section{Jan Zienkowski}

To cite this article: Jan Zienkowski (2018): Politics and the political in critical discourse studies: state of the art and a call for an intensified focus on the metapolitical dimension of discursive practice, Critical Discourse Studies

To link to this article: https://doi.org/10.1080/17405904.2018.1535988

Published online: 19 Oct 2018.

Submit your article to this journal ct?

View Crossmark data 


\title{
Politics and the political in critical discourse studies: state of the art and a call for an intensified focus on the metapolitical dimension of discursive practice
}

\author{
Jan Zienkowski
}

PReCoM (Pôle de Recherches sur la Communication et les Médias), UCLouvain Saint-Louis Bruxelles, Brussels, Belgium

\begin{abstract}
Based on an overview of the ways in which politics and the political have been thought in critical discourse analysis (CDA), the author calls for a focus on the metapolitical dimension of discourse. The author develops his notion of metapolitics on the basis of postfoundational insights into politics, the political and processes of (de-) politicization. Metapolitics refers to projects and struggles where conflicting modes and models of politics clash. Metapolitical debates potentially reshape the structure of the public realm as well as the entities, borders and processes that constitute it. The author differentiates his descriptive and analytic use of the term from the way this signifier has been used programmatically by the anti-democratic New Right and its heirs. He demonstrates that metapolitical projects can be democratic as well as anti-democratic. In order to facilitate discourse analyses of metapolitical projects, debates and struggles, the author suggests that the metapolitical dimension of contemporary debates can be explored further by integrating insights from governmentality studies, studies of political rationality and the discourse theoretical logics approach with CDA. Moreover, a further exploration of the linguistic and textual underpinnings of metapolitics constitutes a promising pathway for future investigation. The study of metapolitics should be part and parcel of the transdisciplinary domain of critical discourse studies so that our understanding of the linguistic and non-linguistic features of metapolitical projects can be developed in equal measure at multiple levels of abstraction.
\end{abstract}

\section{ARTICLE HISTORY}

Received 26 March 2018

Accepted 26 July 2018

KEYWORDS

Politics; politicization; depoliticization; metapolitics; critical discourse studies

\section{Introduction}

Discourse scholars often carry out research with emancipatory political aims in mind (see Blommaert, 2005; Breeze, 2011; Herzog, 2016; Verschueren, 2001; Wodak, 2013). Politics is at once an object of investigation and a driving force for the articulation of discourse analytical critique. These observations alone already necessitate a reflexive attitude with respect to the use of politics-related signifiers in critical discourse studies. In a context where the very meaning of democratic politics is challenged reflection on the category of politics becomes even more important. 
Whether we talk about populist railings against Washington politics, about debates on parliamentary democracy, about the political legacy of the Enlightenment era, or about experiments with participatory democracy and alternative economies, we are dealing with projects that aim to re-imagine and/or change established modes of doing politics. Discourse analysts need to calibrate their understandings of politics and the political to these changing conditions, to take stock of the conceptual tools at their disposal, and to ask whether it is even possible to talk about politics as a singular form.

I argue that we need to explore the fantasies, logics and rationalities that inform metapolitical projects clashing in the public realm. Metapolitics - as I conceptualize it - differs from politics as usual in the sense that it consists of practices that potentially reconfigure existing modes of politics, the associated logics and rationalities, as well as the dominant power structures in a given public sphere. Metapolitical debates have the potential to reshape the structure of a public realm, the entities and processes that constitute it, as well as the concepts and practices of politics that underpin it.

There are only a few overviews of the way notions such as politics and the political have been used in discourse studies. The notion of metapolitics is not used at all in this context. Conceptual discussions about politics in discourse studies are rare and tend to be confined to specific sub-disciplines within the field such as Essex style discourse theory (e.g. Glynos \& Howarth, 2007; Mouffe, 1993, 2005) or (post-) Foucauldian studies of political rationality and governmentality (e.g. Brown, 2015; Foucault, 1978; Mcllveny, Zhukova Klausen, \& Lindegaard, 2016). Nevertheless scholars in discourse theory and analysis have much to gain by paying more attention to the metapolitical dimension of discourse and by reflecting explicitly on their use of signifiers such as 'politics' and (the) 'political'.

I argue that as critical discourse theorists and analysts, we should extend our focus from the study of linguistic and non-linguistic, textual and non-textual political identities, arguments, frames and ideologies to the metapolitical projects wherein such discursive elements get articulated.

In order to make these points, I will first discuss the way the category of politics has been understood by key authors Critical Discourse Analysis. I argue that not enough attention has been paid to radically different 'modes' of conceptualizing and practicing politics in critical discourse studies and in CDA in particular. Secondly, I will show that the field of post-foundational discourse studies contains notions of politics, the political and (de-) politicization that may help us to illuminate the metapolitical struggles of our times. Thirdly, I will outline my preferred notion of metapolitics and distinguish it from the way metapolitics has been conceptualized in New and Alt-Right discourse.

I do not wish to treat New Right (NR) thinkers such as Alain de Benoist on a par with authors in the field of discourse studies and related social sciences. When I first conceptualized metapolitics together with Benjamin De Cleen in a co-authored working paper, I was unaware of the NR use of this term (Zienkowski \& De Cleen, 2017). Nevertheless, in order to distinguish the descriptive and analytical notion of metapolitics advocated in this paper from the NR's anti-democratic and programmatic understanding of the term, we need to shed critical light on NR discourse. Lastly, this paper concludes with an overview of possible pathways of investigation into metapolitics in the field of critical discourse studies. 


\section{Politics and the political in critical discourse analysis (CDA)}

All critical perspectives in discourse studies are political in that they point at the contingent character of discursive practices. They show that things might have been different and that at some point, a political choice has been made to shape things like this and not like that. Critical Discourse Studies is a transdisciplinary field of inquiry where abstract discourse theories focusing on issues of power, subjectivity and knowledge intersect with discourse analytical approaches focusing on language (use), context and practice (Angermuller, Maingueneau, \& Wodak, 2014, pp. 6-7). I will deal primarily with the way key authors in Critical Discourse Analysis (CDA) have conceptualized politics. However, I maintain that my claims about the lack of explicit reflection on the category of politics in CDA also hold for most discourse studies in related (sub-) disciplines such as critical linguistics, cognitive linguistics, systemic functional linguistics, varieties of linguistic pragmatics and/or text linguistics.

CDA frequently focuses on political language, practices, symbols, institutions, arguments, identities, frames, ideologies, logics and/or rationalities materialized in multimodal semiotic forms and constellations. It often relies on insights into the language of politics and into the politics of language generated in linguistic, cognitive, pragmatic and textoriented modes of inquiry (Okulska \& Cap, 2010, pp. 6-7). Nevertheless, in spite of its interdisciplinary richness CDA is marked by a remarkable scarcity of explicit reflection on the category of politics itself.

Key CDA authors did stipulate what they understand by politics, political discourse and/ or political discourse analysis (Chilton, 2004; Chilton \& Shäffner, 1997; Fairclough \& Fairclough, 2012; Van Dijk, 1997; Wodak, 2009). The notion of 'the political' is also a key concept in poststructuralist discourse theory (Mouffe, 2005, pp. 8-14). Nevertheless, definitions of politics and/or the political are often left implicit in texts that deal primarily with political phenomena in terms of ideology, hegemony, power, critique and/or emancipation. Fairclough and Fairclough identify 'a need for more reflection about the connection between views on politics, yiews of political discourse and analytical approaches to political discourse' and that it is 'necessary to work from a coherent view of the nature of politics' when engaging in such reflections (Fairclough \& Fairclough, 2012, p. 17).

CDA scholars rely on rather different frameworks in order to approach politics theoretically and empirically, In an early paper, Van Dijk offers a restrictive take on politics. In order 'to avoid the extension of politics and political discourse to a domain that is so large that it would coincide with the study of public discourse in general' he refuses to label corporate, medical, educational and even media discourse as political discourse. He also writes that 'we shall similarly not take all interpersonal talk (not even of gender) as political discourse' (Van Dijk, 1997, p. 15). Instead, he defines political discourse as 'a special case of political action, and as a functional or strategic part of the political process' (Van Dijk, 1997, p. 15).

The structures and processes of the political domain discussed by Van Dijk include: the societal domain or field of politics; political systems; political values; political ideologies; political institutions; political organizations; political groups; political actors; political relations; political actions; political discourse and political cognition' (Van Dijk, 1997, pp. 16-18). However, it remains unclear why we should content ourselves with a 'more or less arbitrary set of criteria according to which discourse may be categorized as (mainly) political, viz, when it has a direct functional role as a form of political action in 
the political process' (Van Dijk, 1997, p. 23), especially since no definition of politics is provided.

Chilton is careful not to define politics too narrowly and identifies two ways of understanding politics: politics as a power struggle and politics as a cooperative practice of conflict resolution. Both modes of politics can be studied at different levels of analysis: 'At the micro-level there are conflicts of interest, struggles for dominance and efforts at co-operation between individuals, between genders, and between social groups of various kinds'. The micro-level also includes the various techniques we employ to get our way (e.g. persuasion, rational argument, threats, bribes, etc.). At the macro level there are 'the political institutions of the state' that either serve the purpose of dominant individuals or groups, or serve to resolve conflicts of interests, depending on the perspective taken (Chilton, 2004, p. 3).

Chilton relies on Aristotle in order to make the point that language has the function to indicate to a group what is harmful or useful, good or evil, just or unjust. The production and sharing of common views regarding these concepts is 'an intrinsic part of constituting a social or political group' (Chilton, 2004, p. 199). Chilton points out that political discourse is often analysed in terms of exploitation, control and distortion and argues that more attention should go to the cooperative dimension of politics (Chilton, 2004, p. 198). For him, politics is ultimately a negotiation over representations grounded in cognitive interaction. The formation of groups, identities and binary oppositions is shaped by the cognitive set-up of our brains that functions through spatial reasoning, indexicality and a reflexivity that relies on the recursive functions of language for its expression (Chilton, 2004, pp. 201-205).

Machin and Van Leeuwen point out that authors in political science and critical discourse analysis often stick to rather narrow understandings of politics. Inspired by cultural studies they prefer a broader notion of politics that overlaps with the concept of ideology as distributed through mediatized cultural discourse. For them, political discourse is a multimodal phenomenon that can be articulated across contexts and genres, not only in new and old media, but also in design, architecture fashion, product design and other cultural dispositives (Machin \& van Leeuwen, 2016, pp. 244-248).

Wodak grounds her notion of politics more solidly in sociological perspectives. She refers to the division between conflict and cooperation oriented understandings of politics discussed by Chilton and Aristotle. For her, playing the political game implies the imposition of order and knowledge management, the exercise of power to include and exclude, and the formation of coalitions and alliances (Wodak, 2009, p. 26). Other CDA authors would probably agree with this understanding of politics. However, Wodak is less interested in the cognitive dimension of politics and political discourse than Van Dijk and Chilton. Moreover, she stresses politics as a mode of action: 'I assume that 'doing politics' is highly context dependent, influenced by national traditions and political systems, by the habitus of politicians, the modes of performance, the many embodied personality features, organizational structures and antagonistic political interests' (Wodak, 2009, p. 26).

Wodak understands politics as a Bourdieu-like field in which symbolic violence is exercised. She also uses the image of politics as a Luhman-like system intertwined with other systems such as the media or the economy. Politicians - like journalists, historians and sociologists - struggle in their own fields to set out principles of vision and division, but 
also try to impose these principles and to have them recognized as legitimate categories for constructing the social world (Bourdieu 2005, 37 cited in Wodak, 2009, p. 4). Wodak relies on a relatively broad notion of politics and political discourse analysis but for Fairclough \& Fairclough even she needs to be more explicit about the nature of the political process itself.

Okulska and Cap categorize CDA as being part of a broader endeavour they call Analysis of Political Discourse (APD). They argue that the analysis of

political discourse involves not only its institutionalized aspects but virtually any kind of human communication whose objective is to pursue a variety of discourse goals in different (power-marked) social relations and configurations; or, to promote and govern language attitudes forming a basis for societal developments and changes (Okulska \& Cap, 2010, p. 6).

They argue that APD and CDA should incorporate insights into the language of politics (i.e. the rhetorical practices of politicians acting in their political capacity) and into the politics of language (i.e. the political decisions and policies pertaining to official and standard languages, language education and/or language planning), maintaining a close link with approaches in discourse studies such as linguistic pragmatics, cognitive linguistics and critical linguistics in order to guarantee comprehensiveness and structural rigour (Okulska \& Cap, 2010, pp. 7-8)

Fairclough and Fairclough criticize most of the above authors for failing to recognize the fundamentally argumentative nature of politics as deliberation. Even though virtually all authors in CDA recognize that argumentation is part of political discourse, most of them do not place the notion of deliberative argumentation at the centre of their approach to politics. In contrast, Fairclough and Fairclough view 'political discourse as primarily a form of argumentation, and as involving more specifically practical argumentation, argumentation for or against particular ways of acting, argumentation that can ground decision' (Fairclough \& Fairclough, 2012, p. 1). In the following I will show why I consider this deliberative approach to be problematic in the study of metapolitical projects.

Fairclough and Fairclough claim that there is a 'primacy of argumentation in politics'. Other discursive categories and structures (e.g. narratives or explanations) only become political when they provide a background for deliberations that inform political choicemaking (Fairclough \& Fairclough, 2012, p. 13). They define practical argumentation as the balancing of reasons - no matter whether this process happens in hasty, unreasonable, authoritative or even undemocratic ways. They recognize that not all deliberation is marked by the equality of access and freedom from constraints that marks Habermas's ideal speech situation, but also stress that deliberations falling short of normative standards involve argumentation nonetheless (Fairclough \& Fairclough, 2012, p. 14). Fairclough and Fairclough claim that 'a normatively legitimate outcome in politics must satisfy standards of good argumentation' and that 'standards of good politics are intrinsically related to standards for good communication' (Fairclough \& Fairclough, 2012, p. 14). They follow Bohman's adaptation of Habermas in stressing that deliberation should not be geared towards the ideal that all actors involved in a debate agree for the same universal reasons, but towards the twin goals of continued cooperation and compromise (Fairclough \& Fairclough, 2012, pp. 33-34). 
For Fairclough and Fairclough politics is ultimately about decision making: 'Politics is about making choices and decisions about what to do, what action to take in response to a situation' (Fairclough \& Fairclough, 2012, p. 26). Political discourse is deliberative whenever it is oriented to a normative conclusion and when a weighing of reasons took place, 'however minimally' or implicitly (Fairclough \& Fairclough, 2012, p. 27). At the same time, '[p]olitics could be more democratic, and hence in a sense more properly politics, if public practical reasoning were closer to a normative idea of deliberation than it is in practice' (Fairclough \& Fairclough, 2012, p. 27).

Referring to Mouffe, Fairclough and Fairclough seem to favour a mode of agonistic politics as opposed to a politics based on open antagonism and conflict since the former involves a type of cooperation that seems to be more in sync with their deliberative understanding of politics. From Rancière, they draw the lesson that

the art of politics is to reduce the potential for conflict inherent in the division between the aporoi [those without means in the polis] and the euporoi [those with means in the polis] and in the power of the demos, and to accentuate cooperation (Fairclough \& Fairclough, 2012, p. 28).

From Bauman they take the ideas that critical reflection is the very essence of all genuine politics and that it is possible to rely on reflexivity in order to re-invent politics understood as an institutional context that binds actors into complex networks of relations that provide them with reasons for actions (Fairclough \& Fairclough, 2012, pp. 28-29).

Within the CDA literature, the work of Fairclough and Fairclough offers the most thoroughgoing reflection on politics to date. However, they stop short of analysing so-called 'deep disagreements' over politics. As they acknowledge themselves, the analyses on display in their book Political Discourse Analysis 'are not rooted in irreconcilable comprehensive conceptions of the good, but are underlain by a shared framework of moral-political values, freedom, equality, justice', and 'in different interests and different normative priorities that agents assign to (broadly shared) values' (Fairclough \& Fairclough, 2012, p. 34). Put differently, the book does not deal with the metapolitical reinvention of politics and/or the political, an omission that is in all likelihood informed by the deliberative notion of politics as argumentation proposed by the authors themselves. This omission excludes some of the most relevant debates and challenges of our age.

CDA lacks a focus on the different concepts of politics that implicitly and/or explicitly inform particular metapolitical projects, discourses and subjectivities. While it is generally recognized that politics and political discourse get articulated in a wide variety of mediatized contexts, that politics is a specific function of discourse that can be performed by a wide variety of social actors and institutions, and that public debate involves a multiplicity of conflicting political identities, ideologies and discourses, little attention is paid to the different ways in which the notion of 'politics' itself has become an object of struggle.

\section{Politics and the (Meta) political in post-foundational discourse studies}

Referring to Palonen, Peter Muntigl made an observation about CDA that still holds today:

In most cases, politics is equated with the polity or media reports of politicians' actions - the political being an epiphenomenon of particular discursive space - or is cast as the 
construction of differences in terms of 'us' vs. 'them'. Scant mention is given to terms such as politicization, depoliticization, policy, or polity (cf. Palonen, 1993)' (Muntigl, 2002, p. 46)

Palonen distinguishes between policy, polity, politicking and politicization as four ways in which politics is understood today. The contemporary notion of policy thereby refers to 'a direction of activities, to a line, project, plan, program or doctrine' that has 'a teleological connotation, an orientation towards the future, which is considered to be a priority over the present state of affairs as well as the activity itself' (Palonen, 2003, p. 175). The notion of policy thus captures the regulatory dimension of politics. Politicking refers to the improvised and pragmatic performances of actors within a polity that should be understood as 'a metaphorical space that demarcates the 'political sphere' from other spheres' (Palonen, 2003, pp. 177-178). Within the sphere of polity, activities commonly accepted as political are discussed, practiced and planned. Politicking takes place within a historically constituted and therefore inherently instable polity.

Coming rather close to a post-foundational notion of politics, Palonen points out that the a polity is always the 'result of specific politicizations' and that we cannot refer to a proper or ordinary sense of politics' because 'politicization has no quasi-natural subject matter' (Palonen, 2003, p. 182). Politicization therefore involves an 'act of naming something as political, including the controversies surrounding the acceptance of this naming' (Palonen, 2003, p. 182). Palonen's claim that politicization renders some alleged necessities or impossibilities obsolete and may create new time-spaces for action chimes well with critical and post-foundational understandings of politics and the political (Palonen, 2003, p. 182).

It is interesting to note that the post-foundational author Jacques Rancière used the term metapolitics in order to refer to a specific mode of depoliticization that subordinates particular modes of politics to a deeper essence such as the market economy in economic liberalism or to class identity in Marxism (Wilson \& Swyngedouw, 2015, p. 13) ${ }^{1}$. I use the term differently, in order to refer to a mode of politics that acts upon itself and that involves both processes depoliticization and politicization.

Metapolitical projects often reproduce a sense of crisis because they need to foster a sense of urgent change with respect to 'mainstream' policy, polity and politicking. This is not to say that metapolitical projects are always waged outside of the 'sphere' of traditionally accepted politics. However, through politicization alternative time-spaces for action and choice making can be created. Depoliticization closes down such timespaces (Muntigl, 2002, p. 49). For Wood and Flinders, depoliticization and politicization are two faces of the same coin (Wood \& Flinders, 2014, pp. 157, 165). As Maeseele and Raeijmaekers point out:

Depoliticization concerns not only the concealment of those particular politico-ideological values, perspectives and choices that underlie a social order and shape its politics, but also - and more importantly - the misrecognition of the fact that any social order is always the provisional product and expression of a particular configuration of power relations (Maeseele \& Raeijmakers, 2017, p. 4).

This brings us to the post-foundational distinction between politics and the political. In French political theory a distinction is frequently made between la politique or 'politics' (everyday power struggles between politicians in parties, elections, parliaments and 
governments) on the one hand, and le politique or 'the political' which deals with a deeper mode of choice-making and change (Palonen, 2006, p. 16).

For Mouffe, the category of politics includes the domain of everyday parliamentary and extra-parliamentary decision-making - politicking within a polity as well as politics waged in civil society. The notion of 'the political' refers to the idea that social life is always based on decisions made in a prior epoch, to the fact that social reality is the result of a temporary and partial attempt to fix reality in this way and not in another. In the vocabulary of Heidegger, Mouffe distinguishes between 'politics' referring to the 'ontic' level and to 'the political' referring to the 'ontological' level that makes politics possible in the first place (Mouffe, 2005, p. 8; see also Wilson \& Swyngedouw, 2015, pp. 11-16):

By 'the political' I mean the dimension of antagonism which I take to be constitutive of human societies, while by 'politics' I mean the set of practices and institutions through which an order is created, organizing human coexistence in the context of conflictuality proyided by the political (Mouffe, 2005, p. 9)

What is considered to be natural or hegemonic at any point in time is the result of sedimented practices that were once grounded in political decisions (Mouffe, 2005, p. 17). Mouffe claims that there is no final ground on which we can base our identities, values, beliefs and political projects. Notions such as class, the subject, ethnicity and freedom fall away as final grounds for identity formation in Mouffe's post-foundational and antiessentialist project but this does not need to lead to nihilism. The absence of a final ground provides us with a freedom to politicise that is only limited by historically overdetermined conventions and negotiable power relationships (Marchart, 2007, p. 156).

Marchart believes that

democracy is to be defined as a regime that seeks, precisely, to come to terms with the ultimate failure of grounding rather than simply repressing or foreclosing it. He argues that every democracy if it is worth that name, will have to be deliberately post-foundational - a criterion which is not precisely met by everything that goes under the name of democracy today (Marchart, 2007, p. 158).

He summarizes his point as follows: 'not every post-foundational politics is democratic but every democratic politics is post-foundational' (Marchart, 2007, p. 158). Not all forms of politicization are emancipatory or democratic. A notion of metapolitics grounded in post-foundationalinsights allows us to analyse the deep political conflicts of our times as being constituted by clashing emancipatory and anti-democratic modes of politicization, It allows us to see how politics acts upon itself.

\section{Why we should care about metapolitics in discourse studies}

The way politics is usually understood and practiced - politicking within polities, within and outside of parliamentary systems - relies on sedimented but contingent decisions on what counts as a legitimate mode of (de-) politicization within a public realm. The establishment of a society's constitutive and antagonistic outside operates through a rationality that seeks hegemonic status. Because metapolitical projects need to assert and/or defend themselves and their concept of politics from external and internal threats there is a metapolitical dimension to all forms of politics that can be inferred and articulated with different degrees of explicitness and reflexivity. 
When feminist actors politicize practices and issues formerly considered to be private or personal, they may or may not be aware that they are re-imagining the practices and relationships constituting the boundaries of the public sphere. Feminist politics and forms of protest continue to generate new practices, modes of communication and organization, as well as new forms of political subjectivity, as can be exemplified with reference to the recent \#MeToo controversy. Likewise, right-wing populist resistance to and attacks on feminism in the name of a so-called besieged masculinity (see Kelly, 2017), as well as the case of anti-Islamic homo-nationalism (see Bracke, 2012), illustrate how gender-issues are often articulated with (in) wider metapolitical struggles.

Because metapolitical projects can take democratic as well as anti-democratic forms, it is important to identify the particularities of specific metapolitical projects and to go beyond the rather banal observation that there is a metapolitical dimension to all modes of politics. In order to identify the specific metapolitical project underpinning a particular statement or practice one needs to infer the underlying vision of politics and to assess to what extent this vision has implications for the relations between entities and practices constituting a public realm at a given point in time. In doing so, it is useful to make a distinction between metapolitical projects, debates, language use and discourse.

Metapolitical projects consist of programmes, practices and discourses that aim to reconfigure the face of the public sphere. Metapolitical projects clash over the socio-political imaginaries that define the boundaries of what is to count as a legitimate and/or illegitimate political language, practice, subjectivity or mode of organization. The Spanish leftwing populist party Podemos proposes a reversal of post-crisis austerity measures and redraws the boundaries of what is to count as political practice by developing itself simultaneously as a transversal social movement spanning a multiplicity of issues and identities, and as a political party that challenges social democracy while experimenting with alternative modes of practicing and performing politics and politicization (García Agustín \& Briziarelli, 2018, pp. 5-19).

Far right forms of populism are metapolitical projects in that they are antagonistic to post-Enlightenment political configurations and ideologies such as liberalism, socialism and representative democracy. For instance, Victor Orban's 'illiberal democracy' is an anti-democratic metapolitical project that attacks civil society and the separation of powers.

Political debates may revolve around concrete issues such as gender issues, climate change, migration or health care but debates only become metapolitical when their resolution potentially impacts on the logic or rationality that informs the identities, principles and practices that make up a given public sphere. A debate is metapolitical if its outcome may restructure the relationships and identities that constitute a public realm. Moreover, metapolitical debates potentially alter the boundaries between the spheres of activity wherein citizens, civil society organizations, political parties and state institutions exert power. For instance, contemporary European migration debates are not merely about the regulation of migration flows. The questions at stake pertain to the very structure of the European public sphere. Such questions include: how do we define national boundaries and conceptualize citizenship; what is the relationship of citizens and states to officially established values and principles grounded in human rights; and what should be the societal role and function of critical and humanitarian civil society organisations. 
It is also useful to distinguish metapolitical projects from metapolitical language use and discourse. Whereas metapolitical projects include all forms of action geared towards a reconfiguration of dominant modes of doing politics, metapolitical language use refers to linguistic discourse that calls for system-wide change through a (de-) legitimization of particular modes of (de-) politicization and political subjectivity. When metapolitical language use is accompanied by or embedded within other semiotic modalities (e.g. visual, auditory) and practices in patterns within and across specific texts and messages, we will talk about metapolitical discourse. Pro-Trump trolls of the Alt Right rely on language as well as on non-linguistic symbols such as memes in their metapolitical struggle (see Nagle, 2017). Note that it is also possible for political actors to make use of linguistic and non-linguistic metapolitical discourse, only to abandon this rhetoric upon gaining power.

Through metapolitics, politics can act upon itself and upon the political. It is a politics about politics, but not a politics beyond politics. It is not a mode of politics that is merely 'added to' everyday politicking but refers to the actions and processes that make a particular mode of politics possible in the first place. Just as metadiscourse allows us to make sense of everyday texts and communicative practices (Blommaert, 2005, p. 253) and just as meta-communication allows us to regulate everyday communication without going 'beyond' or 'outside' of communication in any way (Bateson, 1954, p. 151), metapolitics reconfigures politics through politics, for better of for worse. In metapolitical struggles, politics reflexively becomes an object for itself.

Reflexive awareness is always limited and comes to us through the spectrum of specific discourses along with their limitations and possibilities (Zienkowski, 2017b). Someone who criticizes a labour union's right to strike may do so with an explicitly anti-corporatist vision of politics in mind but it may also be the case that such a coherent vision is absent and that his or her call for a limitation on the right to strike is simply informed by the inconvenience of arriving late at work due to a syndicalist action in public transport. In the latter case the person involved might provide support for a neoliberal project that aims to limit labour union power without realizing that such a limitation implies a metapolitical reconfiguration of politics as one knows it in a particular public sphere (Zienkowski \& De Cleen, 2017). Metapolitical projects may be articulated with varying degrees of reflexive awareness.

\section{The metapolitics of proto-fascist, New Right and Alt-Right discourse}

We need to distinguish the analytical and descriptive notion of metapolitics advocated above from the programmatic anti-democratic concept of metapolitics developed by the New Right (NR). It is therefore necessary to engage critically with NR discourse on metapolitics. I will now (1) focus on the way NR authors have used the notion of metapolitics in order to (2) show how we can understand the project of the NR as one (undemocratic) metapolitical project among others. Moreover, (3) by exploring the way the NR problematizes the legacy of the Enlightenment, it becomes clear why politicization is not necessarily a democratic process and why we need to focus on the specific ways in which metapolitical projects articulate themselves through specific ideological discourses.

In his book Metapolitics, Peter Viereck pointed out that the German word Metapolitik was first used in Wagner's nationalist circle in order to designate a brand of nationalism 
that supposedly supersedes or goes beyond the politicking associated with parliamentary democracy. Viereck quotes an open letter from a German nationalist to Wagner: 'to be genuinely German, politics must soar to metapolitics. The latter is to commonplace pedestrian politics as metaphysics is to physics' (Frantz, 1878 cited in Viereck, 2003, p. 50; Viereck, 2004, p. 4). It is here that we can catch a first glimpse of the programmatic understanding of metapolitics that can be found in New Right and Alt-Right articulations of the term.

In order to deconstruct and criticize the Nazi-project, Viereck equates metapolitics with a specifically German 'semi-political ideology' or 'atmosphere' that articulates Wagner's romanticism, the so-called 'science of racism', a vague economic socialism and a mystified glorification of the Volk collective in Nazi ideology (Viereck, 2004, p. 4). The New and AltRight drop this German-centred focus and put a Gramsci-inspired spin on the word.

As the French NR or Nouvelle Droite (ND) sought to establish itself as an alternative to violent right wing extremism on the one hand and traditional far right politics on the other hand, its main ideologue - Alain de Benoist - programmatically proposed an anti-egalitarian 'metapolitics' (Capra Casadio, 2014, p. 51). Benoist is the primary theoretician of the Nouvelle Droite - a political ideology that denounces Nazism and its biological racism at the explicit level but whose ideology is inherently and explicitly anti-egalitarian, homogenizing and hierarchical (Bar-On, 2014, pp. 27-28). In his writings, at least three senses of the metapolitical intersect.

Firstly, metapolitics refers to a political strategy based on Gramsci's cultural understanding of hegemony, to what Benoist called 'right-wing Gramscism' (Arnstad, 2015, p. 200). The NR notion of metapolitics refers exclusively to a right-wing cultural battle for the minds and hearts of the population waged by its intellectual elites. It also refers to the formation of such elites. There is a clear and explicit parallel with Gramsci's notion of hegemony (Arnstad, 2015, p. 200; Bar-On, 2014, p. 21, 33; Capra Casadio, 2014, pp. 52-56; Eagleton, 1996; Griffin, 2000, p. 43; Salzborn, 2016, p. 40). When NR writers denounce Gramsci, as is the case in the GRECE ${ }^{2}$ manifesto of 2000 (see de Benoist \& Champetier, 1999 cited in Capra Casadio, 2014, p. 51), this only happens for the 'metapolitical' purpose of delegitimizing the cultural legacy of Marxism. Such denunciations are frequently contradicted elsewhere.

Metapolitics in the second sense is a politics waged outside of traditional militant, activist and parliamentary party-politics, within the cultural sphere (Bar-On, 2014, p. 12). Here, the prefix 'meta' signifies 'outside' of party political structures:

[...] we chose a metapolitical strategy that, according to Gramsci's teachings, allows us to gain cultural power before political power, which does not exclude that in the near future someone could bring our cultural programs to a more political plane (de Benoist, 1981 cited in Capra Casadio, 2014, p. 54).

Benoist does not advocate just any metapolitics. His programme involves a metapolitics that rejects administrative and legal equality, the 'religion of human rights' as well as the legacy of the Enlightenment and the French revolution. Like the fascists of the Interbellum, adherents of the NR claim to have synthesized or moved beyond the 'out-dated' left-right distinction (Bar-On, 2014, pp. 1-2, 30-31). Their project strives towards an alternative modernity and therefore positions itself in opposition to the Enlightenment projects of liberalism, socialism and Marxism (Bar-On, 2012, p. 48). 
The New Right articulates ideas of the Conservative Revolution on organic cultural and civilizational degeneration and rebirth with New Left cultural and political strategies. Inspired by the ethos of the German Cultural Revolution - the proto-fascist intellectual movement that was a key source of inspiration for Nazism - NR authors ritually proclaim that we live in an age of civilizational decline that is a consequence of misguided Enlightenment egalitarianism and of the culturally dislocating forces of Modernity (Griffin, 2000, pp. 38-39).

The NR does not propose a return to pre-modern times but seeks to establish new myths that provide a spiritual basis for a Europe structured along homogeneous and organic ethno-pluralist lines where communal belonging is not based on individual rights but on duties to your region, nation, and Europe. It implies a hostility regarding parliamentary politics and to liberal democracy in general. The NR is decidedly against multiculturalism. It embraces elite rule, and rejects the egalitarian views on human beings developed in socialism, communism, social democracy and liberalism (Bar-On, 2012, pp. 45-47; Salzborn, 2016, pp. 41-47). The NR rejects excessive individualism, unrestrained capitalism, egalitarianism, liberalism, neo-liberalism, socialism, communism, multiculturalism, feminism, and LGBTQ rights but accepts modern secularism, scientific modes of analysis, economic dynamism, and technological process (Bar-On, 2012, pp. 30-31). The ideal NR society includes 'a capitalist market constrained by ethnically conscious, activist elites and 'the people' (that is, one's own ethnic group employing techniques of 'direct democracy' such as referenda) in a collectivist, corporatist vision' (Bar-On, 2014, p. 29). Egalitarianism is considered to be 'the major ill of the modern world' (Bar-On, 2014, p. 27).

We thus find three overlapping notions of metapolitics: metapolitics as a political strategy; metapolitics as intellectual leadership; and metapolitics as a programmatic attempt to replace the legacy of Enlightenment egalitarianism with a decidedly Modern and fascist model of society. The works of Alain de Benoist have impacted on right-wing populist discourses and strategies in Europe and in the US. In the seventies, metapolitics referred to a cultural struggle waged in civil society, magazines, newspapers, literature and pseudo-academic books. Today this struggle is also waged online. For instance, Metapedia is a fascist and racist alternative to Wikipedia that operates in sixteen languages and aims to be a web resource for right-wing activists. The website explicitly presents itself as a 'fact of metapolitical struggle' in the spirit of Alain de Benoist (Metapedia cited in Arnstad, 2015, pp. 199-200). It contains a highly reflexive mission statement that stresses the importance of being able to determine the definition of words and the interpretation of historical events, criticizing 'concepts such as "xenophobia"' that supposedly pathologize 'previously natural and sound values and attitudes' (Metapedia cited in Arnstad, 2015, pp. 199-200).

The strategic and programmatic notion of metapolitics also appears in the self-conceptualisation of the so-called Alt-Right. White supremacist Richard Spencer explicitly frames the goals of his online journal in metapolitical terms: 'RADIX publishes original work on culture, race, tradition, meta-politics, and critical theory' (RADIX, 2017). On AltRight.Com, Daniel Friberg describes metapolitics as 'a war of social transformation, at the level of worldview, thought, and culture'. For Friberg, 'any parliamentary struggle must be preceded, legitimised, and supported by a metapolitical struggle'. Moreover, 'at its best' metapolitics 'reduces parliamentarism to a question of mere formalities' (Friberg, 2015). For him, metapolitics 'creates, encourages, inspires, and illuminates' the path to 'an authentic right' 
and a 'European renaissance' (Friberg, 2015). Metapolitics is not the prerogative of the intellectual leadership at the helm of the NR though. Activities such as the distribution of memes, shit-posting, tweeting, anonymous signalling tactics, and trolling are explicitly categorized as 'a form of dirty and lawless skirmisher warfare, carried out by non-centrallyorganised partisans' in a 'subjective metapolitical war' against 'the global parasite class' by AltRight online activists such as James Lawrence (Lawrence, 2016).

\section{Conclusions and future pathways for investigation}

The metapolitical project of the NR seeks to go 'beyond' the legacy of Enlightenment informed ideologies and modes of politics. In contrast, the notion of metapolitics I argue for shares none of the NR's anti-democratic programmatic connotations. My descriptive and explanatory notion of metapolitics refers to modes of politics that: (1) aim to reconfigure the face of the public sphere; (2) redefine what is to be considered a legitimate mode of practicing politics; and (3) reconceptualise the relationship between politics and the political.

Metapolitical debates are important to critical discourse studies because they potentially restructure the boundaries, relationships and identities that constitute our public realms. The outcome of such debates affects the way power is exercised within and across different sections of the public realm. Metapolitical projects may be democratic or anti-democratic. They are highly reflexive endeavours that aim to reconfigure existing modes of politics. Metapolitics is never a politics outside or beyond politics but always a politics that aims to reconfigure the existing political constellations constitutive of a public realm.

My call to focus on metapolitics in discourse studies is informed by the need to come to terms with conflicting attempts to restructure established modes of political practice and subjectivity. Many contemporary debates do not revolve around isolated topics and issues but around interlinked controversies whose resolution potentially impacts on the political relations, subjectivities and rationalities that shape our public spheres. The growing popularity of right-wing populism in Western Europe and in the US as well as the experiments with participatory modes of politics on the left are indicative of a re-politicization of social life in general and of the category of politics itself. The same can be said of the rise of political Islam and about post-political attempts in the radical centre to move either 'beyond' left and right, or to embrace them both.

Metapolitical projects - be they emancipatory or anti-democratic - offer powerful visions and incentives for achieving social and political change. If we are to understand the metapolitical projects that aim to restructure our public spheres from a discourse analytical perspective, we need to investigate deep conflicts about the nature of politics and the political itself. We cannot content ourselves with modes of discourse analysis that exclusively focus on practical argumentation, on deliberative rationality and/or on narrow understandings of political practice. Authors in post-foundational discourse studies offer a useful distinction between politics and the political and sophisticated accounts of (de-) politicization. They also provide concepts that explain how and why new metapolitical projects take the forms they do. A full account of useful poststructuralist concepts for the study of metapolitics falls outside of the scope of this article, but I will suggest four promising pathways to describe, explain and understand 
the large-scale constellations of signifiers and practices that inform the metapolitical projects of our times.

Firstly, metapolitical projects can be studied from the perspective of governmentality studies. Foucauldian understandings of discourse and power such as power/knowledge and the microphysics of power have been incorporated into CDA but we are dealing with a very selective reading of Foucault's work (Martin Rojo, 2015). Notions such as pastoral power, bio-power, and governmentality usually fall outside of the scope of CDA which arguably 'got stuck on Foucault circa early 1970s, e.g. in his writings such as 'Politics and the Study of Discourse', 'The Discourse on Language' or, in a later translation, 'The Order of Discourse" (Mcllveny et al., 2016, pp. 19-20). In the mean time entire domains of investigation have been constructed around other Foucauldian concepts (Brown, 2015; Lawrence, 2016; Lemke, 2002; Rose, O'Malley, \& Valverde, 2006). For instance, the notion of governmentality only recently acquired significant attention from critical analysts of discourse (Martin Rojo, 2015; Mcllveny et al., 2016, pp. 19-24).

Governmentality involves rationality in the sense of a style of thinking and rendering reality thinkable in such a way that it becomes amenable to calculation and programming. Miller and Rose argue that rationality should always be thought about in the plural, in terms of rationalities. Governmentality is also constituted through technologies that should be understood as 'assemblages of persons, techniques, institutions, instruments for the conducting of conduct', in the Foucauldian sense of the word (Miller \& Rose, 2008, pp. 15-16). If metapolitical projects are to be investigated through the lens of governmentality studies, one needs to focus on the conduct of political conduct and on the various discourses and technologies that form the conditions of possibility for politics to be recognized and practiced as politics. The development and clash of competing metapolitical projects could thereby by analysed in tandem with an analysis of the technological practices that transform and/or reproduce political practices, institutions and subjectivities.

Secondly, metapolitical projects can also be analysed in terms of political rationality. For Foucault political reason 'is not timeless or universal, but always comes in a particular form, secures and circulates specific norms, and posits particular subjects and relations' (Brown, 2015 , p. 115). Brown points out that 'political rationality is not an instrument of governmental practice, but rather the condition of possibility and legitimacy of its instruments, the field of normative reason in which it is forged' (Brown, 2015, p. 116). A political rationality is not in itself a form of governing but the condition of possibility and legitimacy of its instruments (see Brown, 2015, p. 121).

For Foucault, political rationalities are world-changing, hegemonic orders of normative reason, generative of subjects, markets, states, law, jurisprudence and their relations. Political rationalities are always historically contingent, rather than necessary or teleological; however, once ascendant, they will govern as if they are complete and true until or unless challenged by another rationality (Brown, 2015, p. 121).

A third notion useful for exploring the large-scale configuration of metapolitical struggles is the notion of logic as developed in post-foundational discourse theory (Glynos \& Howarth, 2007). Based on the seminal work of Laclau and Mouffe (Laclau \& Mouffe, 1985), Glynos and Howarth developed a mode of theoretical explanation that understands phenomena in terms of the 'logics' that make them possible. The naming and the 
description of these logics requires an analysis of the way signifiers, subject positions, norms, values, narratives and practices get articulated into the discursive structures that inform our sense of self and our sense of reality (Glynos \& Howarth, 2007; Zienkowski, 2017a).

Glynos and Howarth distinguish between political, social and fantasmatic logics. There are two political logics: a logic of equivalence and a logic of difference. The political logic of equivalence refers to the principle whereby different discursive elements are made equivalent to each other by opposing them to a threatening but constitutive outside (Laclau \& Mouffe, 1985). The populist elite-people antagonism figures as the archetypical example here (De Cleen, 2006; De Cleen \& Carpentier, 2010). In contrast, the age-old principle of divide-and-rule can be taken as an example of a mode of politics where the political logic of difference becomes more dominant (Glynos \& Howarth, 2007).

The naming and the description of social logics allow researchers to 'characterise practices in a particular social domain'. Social logics articulate rules, norms, and self-understandings that inform social practices in historically specific configurations (Glynos \& Howarth, 2007, p. 15). For example, one could argue that Belgian post-WWII labour politics have been dominated by social logics of consultation or negotiation. Such social logics entail the operation of a set of rules (e.g. union law or informal procedures structuring consultation processes), norms (e.g. a pro-union norm in most workplaces) and practices that have come under increasing pressure in a time of neoliberal metapolitics (see Zienkowski \& De Cleen, 2017).

The notion of fantasy helps us to understand the affective appeal of metapolitical projects for subjects who get gripped by metapolitical discourse through desire and enjoyment (see Glynos, 2008; Glynos \& Howarth, 2007, pp. 141-152). Fantasmatic logics do not 'set up an illusion that provides a subject with a false picture of the world', but 'ensure that the radical contingency of social reality - and the political dimension of a practice more specifically - remains in the background' (Glynos \& Howarth, 2007, p. 145). Fantasy has a narrative structure that posits an ideal and an obstacle to be overcome. It allows actors to transgress the reality in which they find themselves. It 'offers the subject with a degree of protection from the anxiety associated with a direct confrontation with the radical contingency of social relations' (Glynos, 2008, p. 287). It allows actors to imagine their ideals as achievable goals and their identities as objects of desire that can be filled with concrete contents. Metapolitical projects operate simultaneously through social, political and fantasmatic logics.

Metapolitical debates, projects and discourses are complex phenomena whose analysis requires abstract discourse theoretical notions that allow us to identify the discursive patterns that structure different forms of conceptualizing and practicing politics within, across and beyond specific forms of (multimodal) language use, practices and institutions. However, such patterns always emerge through the performance of concrete linguistic, textual and/or multimodal acts of communication articulated and performed by a multiplicity of voices and actors in the public sphere. Future investigations into metapolitics should therefore also draw on discourse analytical insights generated in more linguistically oriented modes of analysing political discourse. Insights into the politics of language use and into the language of politics generated in sub-domains of discourse studies such as critical linguistics, linguistic pragmatics and different types of CDA (see Okulska \& Cap, 2010, pp. 6-7), should be deployed in combination with a critical reflection on the 
concepts of politics that underlie political discourse on the one hand and political discourse analysis on the other hand. An investigation of the linguistic and multimodal resources actors use to construct metapolitical projects is another research track to be developed further. As such, I argue that the study of metapolitics should be part and parcel of the transdisciplinary domain of critical discourse studies so that our understanding of the linguistic and non-linguistic features of metapolitical projects can be developed in equal measure at multiple levels of abstraction.

\section{Notes}

1. Alain Badiou also wrote about metapolitics. However, his concept is unrelated to the concept I develop in this paper. Badiou wrote about metapolitics in order to criticize political philosophy. For him 'metapolitics' refers to 'whatever consequences a philosophy is capable of drawing, both in and for itself, from real instances of politics as thought. Metapolitics is opposed to political philosophy, which claims that since no such politics exist, it falls to philosophers to think 'the' political' (Badiou, 2011, p. xxxviii).

2. GRECE stands for Groupement de Recherche et d'Etudes pour la Civilization Européenne and is a think tank of the French Nouvelle Droite founded in 1969.

\section{Disclosure statement}

No potential conflict of interest was reported by the author

\section{Notes on contributor}

Jan Zienkowski is guest professor in information and communication science at the UCLouvain SaintLouis Bruxelles, Belgium. Currently, he also works as a post-doc researcher for the LITME@WORK project conducted at the same university. This PReCoM (Pôle de Recherches sur la Communications et les Media) project focuses on the discourse of digital media literacy in teamwork and distance work. He is author of Articulations of self and politics in activist discourse (2017). His publications focus on issues of reflexivity, critique and discourse as articulated in large-scale debates on migration, populism and neoliberalism. He works with linguistic pragmatic, critical and poststructuralist approaches to signification in order to understand how human beings deal with hegemony with varying degrees of awareness. He has a background in communication sciences, international relations and linguistics. Jan Zienkowski, PReCoM (Pôle de Recherches sur la Communication et les Médias), UCLouvain Saint-Louis Bruxelles, 43 Boulevard du Jardin botanique (building 38 desk F6), 1000 Brussels, Belgium.

\section{ORCID}

Jan Zienkowski (D) http://orcid.org/0000-0001-8240-3695

\section{References}

Angermuller, J., Maingueneau, D., \& Wodak, R. (2014). The discourse studies reader: An introduction. In J. Angermuller, D. Maingueneau, \& R. Wodak (Eds.), The discourse studies reader (pp. 1-14). London: John Benjamins Publishing Company.

Arnstad, H. (2015). Ikea fascism: Metapedia and the internationalization of Swedish generic fascis. Fascism: Journal of Comparative Fascist Studies, 4(2), 194-208.

Badiou, A. (2011). Metapolitics. London: Verso. 
Bar-On, T. (2012). The French New Right's quest for alternative modernity. Fascism: Journal of Comparative Fascist Studies, 1(1), 18-52.

Bar-On, T. (2014). The French New Right: Neighther right, nor left? Journal for the Study of Radicalism, $8(1), 1-44$.

Bateson, G. (1954). A theory of play and fantasy. In G. Bateson (Ed.), Steps to an ecology of mind (pp. 150-172). London/Toronto/Sydney/New York: Paladin Granada Publishing.

Blommaert, J. (2005). Discourse. Cambridge: Cambridge University Press.

Bourdieu, P. (2005). The political field, the social science field, and the journalistic field. In R. Benson, \& E. Neveu (Eds.), Bourdieu and the journalistic field (pp. 29-47). Cambridge: Polity Press.

Bracke, S. (2012). From 'saving women' to 'saving gays': Rescue narratives and their dis/continuities. European Journal of Women's Studies, 19(2), 237-252.

Breeze, R. (2011). Critical discourse analysis and its critics. Pragmatics, 21(4), 493-525.

Brown, W. (2015). Undoing the demos: Neoliberalism's stealth revolution. Cambridge: MIT Press.

Capra Casadio, M. (2014). The New Right and metapolitics in France and Italy. Journal for the Study of Radicalism, 8(1), 45-86.

Chilton, P. (2004). Analysing political discourse: Theory and practice. London/New York: Routledge.

Chilton, P., \& Shäffner, C. (1997). Discourse and politics. In T. A. Van Dijk (Ed.), Discourse as social interaction (pp. 206-230). London: Sage Publications.

de Benoist, A. (1981). Intervista esclusiva con Alain de Benoist: Cambiare la mentalità per vincere la decadenza/Interviewer: G. B. Luca Nicchi. (Vol 40), Dissenso.

de Benoist, A., \& Champetier, C. (1999). La Nouvelle Droite de l'an 2000. Eléments.

De Cleen, B. (2006). Multiculturalism and 'saying it like it is': Mapping discourses of political correctness in North Belgium. In N. Carpentier, P. Pruulmann-Vengerfeldt, K. Nordenstreng, M. Hartmann, P. Vihalemm, \& B. Cammaerts (Eds.), Researching media, democracy and participation (pp. 83-94). Tartu: Tartu University Press.

De Cleen, B., \& Carpentier, N. (2010). Contesting the populist claim on "the people" through popular culture: The 0110 concerts versus the Vlaams Belang. Social Semiotics, 20(2), 175-196.

Eagleton, T. (1996). Ideology: An introduction. London: Verso.

Fairclough, N., \& Fairclough, I. (2012). Political discourse analysis: A method for advanced students. Padstow: TJ International Ltd.

Foucault, M. (1978). Politics and the study of discourse. In G. Burchell, C. Gordon, \& P. Miller (Eds.), The foucault effect: Studies in governmentality (pp. 53-72). London: Harverster Wheatsheaf. (Reprinted from: 1991).

Frantz, C. (1878). Offener brief an Richard Wagner. Bayreuther Blätter, 1(169), 149-170.

Friberg, D. (2015). Metapolitics from the Right. ALTRIGHT.COM. Retrieved from https://altright.com/ 2015/11/30/metapolitics-from-the-right/

García Agustín, Ó, \& Briziarelli, M. (2018). Introduction: Wind of change: Podemos, its dreams and its politics. In O. García Agustín, \& M. Briziarelli (Eds.), Podemos and the new political cycle: Left-wing populism and anti-establishment politics (pp. 3-22). Cham: Palgrave Macmillan.

Glynos, J. (2008). Ideological fantasy at work. Journal of Political Ideologies, 13(3), 275-296.

Glynos, J., \& Howarth, D. (2007). Logics of critical explanation in social and political theory. London: Routledge.

Griffin, R. (2000). Between metapolitics and apoliteia: The Nouvelle Droite's strategy for conserving the fascist vision in the 'interregnum'. Modern \& Contemporary France, 8(1), 35-53.

Herzog, B. (2016). Discourse analysis as social critique. London: Palgrave Macmillan.

Kelly, A. (2017). The Alt-Right: Reactionary rehabilitation for white masculinity. Soundings, 66(66), 6878. doi:10.3898/136266217821733688.

Laclau, E., \& Mouffe, C. (1985). Hegemony and socialist strategy: Towards a radical democratic politics. London: Verso.

Lawrence, J. (2016). The role of trolling. Retrieved from http://alternative-right.blogspot.com.es/2016/ 06/the-role-of-trolling.html

Lemke, T. (2002). Foucault, governmentality, and critique. Rethinking Marxism, 14(3), 49-64.

Machin, D., \& van Leeuwen, T. (2016). Multimodality, politics and ideology. Journal of Language and Politics, 15(3), 243-258. doi:10.1075/jlp.15.3.01mac. 
Maeseele, P., \& Raeijmakers, D. (2017). Nothing on the news but the establishment blues? Toward a framework of depoliticization and agonistic media pluralism. Journalism, 1-18. Advance online publication. doi:10.1177/1464884917739476

Marchart, O. (2007). Post-foundational political thought: Political difference in Nancy, Lefort, Badiou and Laclau. Edinburgh: Edinburgh University Press.

Martin Rojo, L. (2015). Five foucauldian postulates for rethinking language and power. Working Papers in Urban Language and Literacies, 176, 22. Retrieved from https://www.academia.edu/ 16881720/WP176_Mart\%C3\%ADn_Rojo_2015._Five_Foucauldian_postulates_for_rethinking_ language_and_power

Mcllveny, P., Zhukova Klausen, J., \& Lindegaard, L. B. (2016). New perspectives on discourse and governmentality. In P. Mcllveny, J. Zhukova Klausen, \& L. B. Lindegaard (Eds.), Studies of discourse and governmentality (pp. 1-72). Amsterdam: John Benjamins Publishing Company.

Metapedia. Mission statement. Retrieved from http://www.metapedia.org/mission.php

Miller, P., \& Rose, D. (2008). Governing the present. Cambridge: Polity Press.

Mouffe, C. (1993). The return of the political. London: Verso.

Mouffe, C. (2005). On the political. London/New York: Routledge.

Muntigl, P. (2002). Politicization and depoliticization: Employment policy in the European Union. In P. Chilton, \& C. Schäffner (Eds.), Politics as text and talk: Analytic approaches to political discourse (pp. 45-79). Amsteram: John Benjamins.

Nagle, A. (2017). Kill all normies: Online culture wars from 4Chan and Tumblr to Trump and the New Right. Alresford: Zero Books.

Okulska, U., \& Cap, P. (2010). Analysis of political discourse: Landmarks, challenges and prospects. In U. Okulska, \& P. Cap (Eds.), Perspectives in politics and discourse (pp. 3-20). Amsterdam: John Benjamins.

Palonen, K. (1993). Introduction: from policy and polity to politicking and politicization. In K. Palonen, \& T. Parvikko (Eds.), Reading thepolitical: Exploring the margins of politics (pp. 103-121). Helsinki: FPSA.

Palonen, K. (2003). Four times of politics: Policy, polity, politicking, and politicization. Alternatives, 28 (2), 171-186.

Palonen, K. (2006). Two concepts of politics. Distinktion: Journal of Social Theory, 7(1), 11-25.

RADIX. (2017). About radix journal. Retrieved from http://www.radixjournal.com/about/

Rose, N., O'Malley, P., \& Valverde, M. (2006). Governmentality. Annual Review of law and Social Science, 2, 83-104.

Salzborn, S. (2016). Renaissance of the New Right in Germany? A discussion of New Right elements in German right-wing extremism today. German Politics and Society, 34(119), 36-63.

Van Dijk, T. A. (1997). What is political discourse analysis? Belgian Journal of Linguistics, 11(1), 11-52. Verschueren, J. (2001). Predicaments of criticism. Critique of Anthropology, 21(1), 59-81.

Viereck, P. (2003). Metapolitics revisited. Humanitas, 16(2), 48-75.

Viereck, P. (2004). Metapolitics: From wagner and the German romantics to hitler (expanded edition ed.). New Brunswick and London: Transaction Publishers.

Wilson, J., \& Swyngedouw, E. (2015). Seeds of dystopia: Post-politics and the return of the political. In J. Wilson, \& E. Swyngedouw (Eds.), The post-political and its discontents: Spaces of depoliticisation, spectres of radical politics (pp. 1-22). Edinburgh: Edinburgh University Press.

Wodak, R. (2009). The discourse of politics in action: Politics as usual. Houndmills: Palgrave MacMillan. Wodak, R. (ed.). (2013). Critical discourse analysis: Concept, history, theory (Vol. 1). London: Sage.

Wood, M., \& Flinders, M. (2014). Rethinking depoliticisation: Beyond the governmental. Polity \& Politics, 42(2), 151-170.

Zienkowski, J. (2017a). Articulations of self and politics in activist discourse: A discourse analysis of critical subjectivities in minority debates. Cham: Palgrave Macmillan.

Zienkowski, J. (2017b). Reflexivity in the transdisciplinary field of critical discourse studies. Palgrave Communications, 3, 17007. doi:10.1057/palcomms.2017.7.

Zienkowski, J., \& De Cleen, B. (2017). De-legitimizing labour unions: on the metapolitical fantasies that inform discourse on striking terrorists, blackmailing the government and taking hard-working citizens hostage. Tilburg Papers in Culture Studies, (176). Retrieved from https://www.tilburguniversity. edu/research/institutes-and-research-groups/babylon/tpcs/item-paper-176-tpcs.htm 